
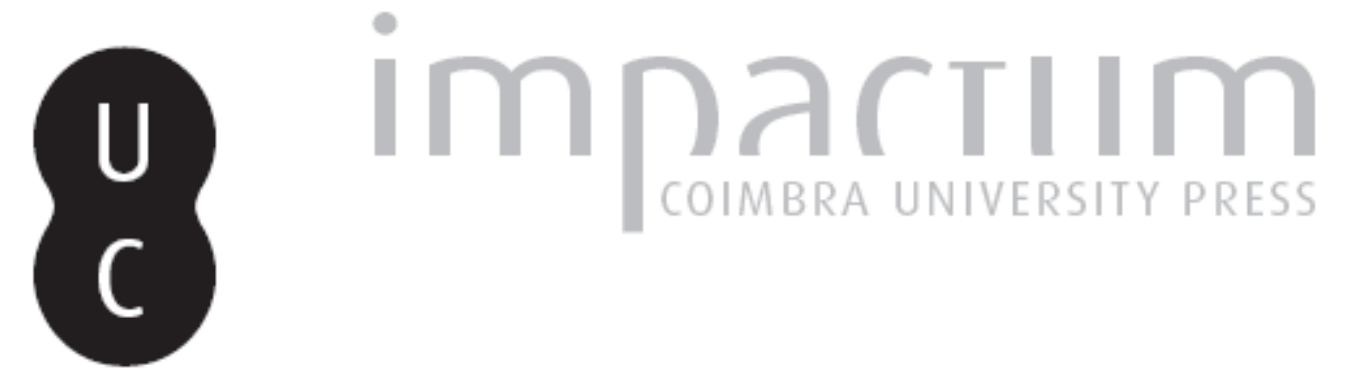

\title{
Sobre dois capitéis de Lisboa
}

Autor(es): $\quad$ Fernandes, Lídia

Publicado por: Faculdade de Letras da Universidade de Coimbra

URL persistente:

URI:http://hdl.handle.net/10316.2/37673

DOI:

DOI:http://dx.doi.org/10.14195/1647-8657_41_11

Accessed : $\quad$ 26-Apr-2023 10:45:02

A navegação consulta e descarregamento dos títulos inseridos nas Bibliotecas Digitais UC Digitalis, UC Pombalina e UC Impactum, pressupõem a aceitação plena e sem reservas dos Termos e Condições de Uso destas Bibliotecas Digitais, disponíveis em https://digitalis.uc.pt/pt-pt/termos.

Conforme exposto nos referidos Termos e Condições de Uso, o descarregamento de títulos de acesso restrito requer uma licença válida de autorização devendo o utilizador aceder ao(s) documento(s) a partir de um endereço de IP da instituição detentora da supramencionada licença.

Ao utilizador é apenas permitido o descarregamento para uso pessoal, pelo que o emprego do(s) título(s) descarregado(s) para outro fim, designadamente comercial, carece de autorização do respetivo autor ou editor da obra.

Na medida em que todas as obras da UC Digitalis se encontram protegidas pelo Código do Direito de Autor e Direitos Conexos e demais legislação aplicável, toda a cópia, parcial ou total, deste documento, nos casos em que é legalmente admitida, deverá conter ou fazer-se acompanhar por este aviso.

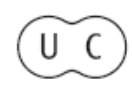




\section{CONIMBRIGA}

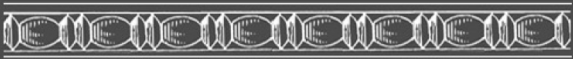

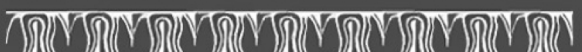
2

INSTITUTO DE ARQUEOLOGIA

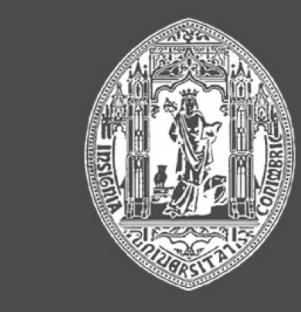

VOLUME XLI - 2002

F A C U L D A E D E LETRAS UNIVERSIDADE DE COIMBRA 
LÍDIA FERNANDES

Arqueóloga do Serviço de Arqueologia da Divisão de Museus e Palácios Municipais da Câmara Municipal de Lisboa - Museu da Cidade. Mestre em História de Arte.

\section{SOBRE DOIS CAPITÉIS DE LISBOA}

"Conimbriga" XLI (2002) p. 237-256

Resumo: Analisam-se dois capitéis da ordem coríntia encontrados na Rua das Padarias, em Lisboa, na década de 1960. Actualmente estas peças são propriedade privada, sendo objectivo do presente estudo a sua divulgação.

Para além da boa qualidade técnica e pormenores decorativos, estes espécimes apresentam a particularidade de, provavelmente, não se encontrarem concluídos, o que nos permite apresentar algumas considerações acerca dos ateliers onde foram realizados.

ABSTRACT: An analysis is presented of two capitals of corinthian style found in Lisbon - Rua das Padarias - in the 60's years. They are now individual property. The actual text is aimed to divulge these good samples of this architectonic order.

The importance of these pieces, for more then a good technical execution and stylistics particularities, reside in the fact these capitals probably correspond to unfinished pieces. Some suggestions are presented about the production atelier. 
(Página deixada propositadamente em branco) 


\section{SOBRE DOIS CAPITÉIS DE LISBOA}

\section{INTRODUÇÃO}

As peças que apresentamos revelam-se de grande interesse por várias particularidades. Por um lado, pelo facto de serem dos poucos elementos arquitectónicos deste tipo aparecidas em solo olisiponense, para além dos capitéis do teatro romano de Lisboa e de alguns isolados que apareceram na zona antiga da cidade. Por outro, por se tratar de duas peças que evidenciam estádios diferentes de acabamento. Este último aspecto depara-se importante na medida em que poderá evidenciar a existência de oficinas de canteiro na cidade de Olisipo, ainda que a não conclusão dos espécimes torne difícil uma atribuição cronológica precisa.

\section{ANÁLISE DESCRITIVA}

As peças que analisamos são dois capitéis coríntios de coluna que se encontram, actualmente, na casa do Sr. Professor José Hermano Saraiva, em Palmela.

Tivemos oportunidade de estudar estas duas peças aquando do trabalho por nós realizado em 1997 (FERNANDES, 1997) integrado na investigação realizada sobre os capitéis de época romana da Lusitânia ocidental. A importância destes espécimes justifica, a nosso ver, a actual apresentação, quer devido ao seu aparecimento na zona antiga da cidade de Lisboa, bem assim pelas características, morfológicas e estilísticas, por eles evidenciadas.

Estes exemplares estão em muito bom estado de conservação sendo idênticos entre si, quer no que respeita às dimensões quer no que se refere aos aspectos morfológicos.

Por informação do seu actual proprietário, a quem agradecemos a disponibilidade mostrada para a respectiva análise e estudo, sabemos 
que as peças foram encontradas nos finais da década de 1960, em Lisboa, concretamente na Rua das Padarias, quando se procedia no local a obras de remodelação de um edifício (Fig. 1). Estes dois elementos arquitectónicos encontravam-se a cerca de $2 \mathrm{~m}$ de profundidade, nas valas realizadas no exterior de um prédio da rua. Desconhecemos, por conseguinte, o contexto do achado

Denominaremos como "Capitel 1" aquele que se encontra em fase mais atrasada de conclusão, ou seja, onde os pormenores decorativos não se encontram ainda presentes, encontrando-se os vários motivos apenas esboçados na pedra (Fig. 2). Por "Capitel 2", designamos o outro espécime, onde se podem observar os vários ornamentos de pormenor já realizados ou em fase de conclusão (Fig. 3).

$\mathrm{O}$ facto de estes dois capitéis corresponderem a peças inacabadas torna mais difícil, como já referimos, uma identificação cronológica precisa. Não obstante, a análise comparativa que apresentamos permite-nos o delinear de algumas hipóteses. A similitude das peças, quer em termos formais quer em termos de dimensões leva-nos a considerá-las como integrantes de um mesmo programa decorativo de um único edifício, ainda que a ausência de informações quanto ao contexto do achado nos impossibilite o delinear de considerações mais seguras quanto a este aspecto.

\section{Dimensões (cm): Capitel 1}

Altura - 43;

Dimensões do ábaco - $60 \mathrm{X}$ ?;

Altura do ábaco - 3;

Altura imma folia - 12;

Altura summa folia - 26;

Diâmetro - 34

Estado de conservação: três dos quatro ângulos da peça encontram-se partidos na zona do ábaco. $O$ estado de conservação do exemplar, em geral, é bom apesar de algumas das folhas apresentarem a sua parte superior também partida.

Matéria: calcário, pedra de lioz.

\section{Dimensões (cm): Capitel 2}

Altura - 43;

Dimensões do ábaco - 66 X ?;

Altura do ábaco - 3; 
Altura da imma folia - 13;

Altura da summa folia - 26;

Diâmetro - 33

Estado de conservação: muito bom, ainda que o ábaco se encontre partido em três dos seus ângulos.

Matéria: calcário, pedra de lioz.

\section{ANÁLISE COMPARATIVA}

\subsection{Capitel 1}

Este capitel de considerável proporção apresenta a característica de não se encontrar terminado. A decoração mais pormenorizada não está concluída, ainda que os traços decorativos gerais - a sofrerem tratamento posterior - estejam presentes. Torna-se difícil, por tal facto, estabelecer uma análise comparativa pertinente, estilística ou cronológica, devendo as informações que se obtiverem pelo estabelecimento de comparações com outros exemplares, ser relativizadas uma vez que nos encontramos, em definitivo, perante um exemplar inacabado.

Não obstante tais limitações, podemos afirmar que nos encontramos perante um capitel canónico, uma vez que estão presentes, ainda que meramente esboçados, todos os elementos que caracterizam este tipo de capitel.

Algumas das folhas da imma folia apresentam bem demarcados quatro lóbulos. Estes possuem uma morfologia alongada, lanceolada e com uma terminação de perfil arredondado, sem que exista algum ponto de sombra entre eles. Os lóbulos dispõem-se paralelamente, ainda que os dois superiores ligeiramente encurvados, afastando-se do kalathos de forma acentuada. A disposição regular dos pontos de trépano no local onde se situaria a separação lobular permite-nos distinguir cinco lóbulos em cada uma das folhas. A presença de de tal número de lóbulos é característica das folhas coríntias da primeira época imperial.

Paralelos para este tipo de lóbulos não são difíceis de estabelecer. A terminação lobular apresenta uma morfologia relativamente habitual no léxico decorativo do capitel coríntio, ainda que nos pareça menos vulgar o facto de os mesmos se encontrarem dispostos paralelamente. 
Quanto ao primeiro aspecto - a morfologia da terminação dos lóbulos - podemos estabelecer uma evolução traduzida por um progressivo arredondamento destes elementos, facto que se observa, essencialmente, a partir de meados da época augustana, mas cujo modelo pode ser encontrado em épocas anteriores correspondendo à verdadeira definição do acanthus mollis ${ }^{1}$. Observamos lóbulos idênticos em peças provenientes de Óstia datadas da época de Adriano (PENSABENE, 1973 65 n. $\left.{ }^{\circ} 253\right)^{2}$, ou ainda de Barcelona e de Clúnia, as primeiras com uma cronologia enquadrável entre o período tardo-augustano e os inícios da época júlio-cláudia, e as segundas integradas nesta última fase (GUTIERREZ BEHEMERID, 199282 - n. ${ }^{\circ} 226 ; 342$ ). Proveniente de Córdova, um capitel da primeira metade do séc. I apresenta lóbulos alongados com terminação em gota e digitação central, semelhantes aos existentes no presente capitel (CARLOS MARQUEZ, $199374-\mathrm{n} .^{\circ} 111$ ).

Os exemplos que referimos mostram-nos, no entanto, a folha integralmente decorada, o que fornece, à partida, mais informações no que respeita aos pormenores decorativos ao invés do que acontece no exemplar olisiponense. As uniões interlobulares, por exemplo, podem ser integradas em modelos mais ou menos padronizados, dos quais o capitel agora em análise se afasta. Desconhecemos, deste modo, se os lóbulos em presença se organizariam em conjuntos ou se, pelo contrário, se dispunham com a mesma orientação e nascendo, todos eles, do centro da folha. Em alguns locais onde o talhe é mais pormenorizado é possível observar, ainda que tenuamente, um ponto de sombra interlobular que adopta a forma de gota pouco apontada e dispondo-se obliquamente. A confirmar-se esta interpretação estaremos perante morfologias bem determinadas que podemos encontrar em peças ainda dos finais da época republicana, como acontece em capitéis ostienses (PENSABENE 197353 e $54-$ n. ${ }^{\circ} 203 ; 55$ e $56-$ n. ${ }^{\text {os }} 209,212,213$ e 215). Esta será, igualmente, uma característica dos capitéis do período augustano, onde as uniões interlobulares abandonarão progressivamente a forma de pequenos círculos para adoptarem um formato progressivamente mais alongado (PENSABENE 1973 208) colocado de forma oblíqua. Em épocas posteriores essa orientação tenderá para a verticalidade sendo, de igual modo, menos espesso.

1 Em oposição ao acanthus spinosa de origem grega.

2 Este exemplar oferece lóbulos muito semelhantes ainda que ligeiramente mais apontados. 
Os pequenos pontos de trépano que ladeiam lateralmente a folha podem fornecer-nos alguma informação em relação à técnica de talhe deste exemplar (Fig. 4). Com efeito, a colocação de pequenos furos à volta da folha divide a sua superfície preparando-a para a ornamentação mais cuidada. Encontramos, também em Óstia, uma peça que nos oferece um talhe idêntico datável do séc. II (PENSABENE, 197373 n. ${ }^{\circ}$ 292). No capitel da Rua das Padarias esta particularidade deverá ser atribuída ao seu não acabamento, uma vez que não é possível saber se tais pormenores da marcação com trépano teriam um acabamento posterior.

A nervura central é materializada por dois sulcos profundos realizados a trépano. Os vários pontos não se encontram ainda unidos, ainda que, certamente, fosse essa a intenção do canteiro. Os sulcos são curvos, afastando-se entre si na parte superior e inferior. Essa curvatura, bem como a representação da nervura através de sulcos aparece-nos, por exemplo, numa peça ostiense do segundo decénio do séc. II (PENSABENE 197364 e $65-$ n. ${ }^{\circ}$ 250), num outro de Mérida, de meados do séc. I (BARRERA ANTON 198435 e 36 - n. ${ }^{\circ} 25$ ) ou num capitel da catedral de Grado (Itália) dos finais do séc. I (DíAz MARTos 1960-61 230 - fig. 7). O mais vulgar, no entanto, mesmo em peças mais tardias, será a representação de sulcos paralelos ou somente divergindo entre si na parte inferior.

A alteração mais profunda na representação destes elementos será levada a cabo a partir de Trajano, momento em que as alterações estilísticas se traduzem, entre outras, pela realização de caneluras ligeiramente arqueadas, aspecto que será igualmente sublinhado na época de Adriano.

As folhas da segunda coroa apresentam-se muito similares às da imma folia (Fig. 3). Os lóbulos são mais bem desenhados e a digitação central é mais marcada, observando-se um máximo de seis lóbulos, assinalados lateralmente por pontos de trépano. $\mathrm{O}$ afastamento da parte superior da folha em relação ao kalathos é aqui mais acentuada, o que certamente conferiria um maior efeito de sombras e luzes, tornando de igual modo mais evidente o consequente jogo de volumes.

Por entre as folhas desta coroa saem grossos caulículos, dos quais se encontram somente representadas as respectivas orlas (Fig. 5), decoradas por moldura ligeiramente convexa delimitada por sulcos. A parte inferior dos caulículos não se encontra verdadeiramente representada uma vez que não existe separação entre estes e a superfície do 
cesto. Os caulículos apresentam-se quase verticais, aspecto que se observa sobretudo no séc. II, altura a partir da qual se assiste a uma progressiva inclinação destes elementos através de um afastamento nítido em relação ao eixo central da peça (PENSABENE 1973 209). No séc. II, no entanto, prevalecem os caulículos verticais ou ligeiramente inclinados para o exterior. Orlas não decoradas e caulículos lisos não são frequentes. Um capitel dos inícios do séc. I de Óstia oferece-nos uma solução semelhante (PENSABEne 197357 - n. ${ }^{\circ}$ 217) ainda que durante o séc. I, e também no seguinte, a ornamentação mais frequente sejam as caneluras a decorar caulículos e sépalos, de bordo arredondado nas respectivas orlas ${ }^{3}$. Quanto ao nosso exemplar e, mais uma vez, dado o facto da sua decoração não se encontrar concluída, não podemos afirmar se este seria o aspecto definitivo que adoptaria.

Dos caulículos saem caules que suportam meias folhas apenas esboçadas. Estes elementos vegetais seguem as mesmas características dos elementos foliáceos anteriormente analisados. Assim, encontramos também aqui pequenos pontos de trépano que se dispõem lateralmente em relação às meias folhas que suportam as volutas, dispondo-se quase horizontalmente a fim de acompanhar a projecção da mesma. Os talos que saem dos caulículos são lisos e de secção convexa desenhando cada conjunto - caules da voluta e respectiva hélice - um perfil em V não chegando a tocar inferiormente a orla dos caulículos.

É de sublinhar a vegetalização das volutas e hélices. Ainda que desde época helenística se possam encontrar exemplos dessa alteração canónica do capitel coríntio será, essencialmente, em época imperial (sécs. I e II) que tal facto ocorrerá mais frequentemente ${ }^{4}$. Os capitéis coríntios da "Maison Carré de Nîmes" edificada entre 15 e 12 a.C. oferecem-nos volutas vegetais de cariz naturalista.

As hélices elevam-se quase verticalmente ainda que a sua terminação superior altere bruscamente de sentido e o local onde, provavelmente, se localizaria o enrolamento espiraliforme mal apareça esboçado. Ainda que se observe um pequeno alargamento das hastes das hélices junto ao ábaco, parece não haver espaço suficiente para a inclusão das volutas, estas, a serem explanadas, certamente seriam muito contidas.

3 Cf. com capitéis emeritenses júlio-claudianos, vide BARRERA ANTON, 1984, pp. 27-33, n. ${ }^{\text {os }}$ 2-19.

4 Vide Pensabene, 1973, p. 218. 
Se, por um lado, a verticalidade destes elementos nos leva a apontar cronologias mais recuadas, a sua súbita inflexão e o aspecto pesado que elas ostentam, como que segurando o peso do ábaco, leva-nos a estabelecer comparações com peças mais tardias. Assim, em Córdova, capitéis datados de entre os finais do séc. II e o séc. III (CARLOS MARQUEZ 199367 - n. ${ }^{\circ} 96$; 98 - n. ${ }^{\circ} 170$; 99 - n. ${ }^{\circ} 173$ ), bem como exemplares de Itálica (Sevilha) de inícios do séc. II (GUTIERREZ BEHEMERID 1992108 e 109 n. ${ }^{\circ} 466$ ), oferecem-nos características idênticas.

Nos ângulos da peça observamos volutas que apresentam uma acentuada projecção, separando-se do kalathos com o objectivo de acompanhar o ábaco que se lhes sobrepõe. Por baixo das volutas, as folhas que as sustentam oferecem um aspecto de maior força à composição. A orientação quase horizontal que estes elementos adoptam - em oposição à verticalidade acentuada que apresentam nos sécs. I e mesmo no séc. II - aproxima-os de peças tardias do séc. III ou da seguinte centúria, como podemos observar em capitéis coríntios de Perugia (Cenciaioli 1977/78 60 e 61 Tav. XIV).

A área concedida a este último registo decorativo é relativamente pequeno. As duas coroas de folhas ultrapassam mais de um terço da altura total da peça, proporção que se afasta daquela que encontramos até à primeira centúria, quando a altura das duas coroas não ultrapassa metade da altura total da peça. No presente caso, é nítida a desproporção entre o registo foliáceo e a parte das volutas, hélices e ábaco. Tal proporção obriga a um distinto lançamento das hélices e volutas, as quais adquirem um aspecto de certo modo deselegante.

O espaço entre o ábaco e as volutas aparece esvasado, o que indica um trabalho pormenorizado e cuidado, onde os efeitos de claro/ /escuro seriam procurados. Esta característica coaduna-se com a intensa utilização do trépano, provocando sulcos profundos e onde a alternância de volumes é fornecida pelas várias folhas. Trabalho idêntico podemos detectar nos enrolamentos espiraliformes das volutas angulares. A espiral é acentuada e o canal é progressivamente mais relevado à medida que se aproxima do botão central. Frontalmente, as duas fitas que representam o canal unem-se a meio através de um pequeno listel, ao invés da simples junção que encontramos em peças de época augustana ou dos inícios da júlio-cláudia.

O ábaco é estreito, de lados côncavos, oferecendo um perfil vertical e inflectindo para o interior com talhe biselado. As suas faces encontram-se decoradas com motivos distintos, ainda que dois deles se 
encontrem partidos. A tradicional flor foi aqui substituída por elementos pouco usuais no léxico do capitel coríntio canónico. Um dos motivos é uma palmeta muito estilizada a qual, se analisada individualmente, poderíamos integrar em cronologias tardias ${ }^{5}$.

O outro ornato é menos usual no léxico decorativo do capitel coríntio. Tratando-se do motivo de círculos relevados que apenas nos aparece documentado em Córdova, ainda que numa peça de entre os sécs. VIII/IX, de época emiral (CRESSIER 1990 Lám. II n.ํ 12). Será que estaremos perante o desvirtuar de um elemento mais antigo - como parece acontecer num capitel coríntio asiático de Óstia dos finais do séc. IV ou inícios do séc. V, onde as hélices estilizadas foram elevadas para decorar com dois pequenos círculos o local da tradicional flor do ábaco (PENSABENe 1973105 n. ${ }^{\circ}$ 383) - ou estaremos perante um motivo de tradição local? Esta dificuldade de identificação é sublinhada pelo facto de que pode, simplesmente, tratar-se de um motivo não concluído.

Por cima do ábaco detectamos um pequeno scamillus, retraído em relação à dimensão do ábaco, e que se apresenta moldurado (Fig. 2). Este quadrado portante denuncia um tratamento cuidado, sobretudo se tivermos em atenção que se trataria de um elemento que não seria visível.

Semelhante solução, ainda que realizada de forma distinta, pode-se observar no templo de Évora. Aqui, o friso que se sobrepõe aos capitéis apresenta a particularidade de apresentar um ressalto na zona coincidente com o centro dos capitéis com o objectivo de não os danificar, bem como o de concentrar a descarga das forças da parte superior do monumento ${ }^{6}$. Este seria, de igual modo, o objectivo da presença deste scamillus na peça de Lisboa, o que denuncia o conhecimento da projecção estereométrica preparativa do talhe.

Encontramo-nos perante algumas dificuldades na tentativa de uma atribuição cronológica. Por um lado, existem pormenores decora-

5 Alguns exemplares de época visigótica ou, inclusivamente, de época mais tardia. Sobre peças análogas cf. CRUZ VILlalón, 1985. No séc. II constatamos o recurso a este motivo para a decoração do ábaco, ainda que a morfologia das palmetas seja distinta, denotando um trabalho cuidado e estando subjacente uma clara proporção entre o elemento vegetal e a altura do ábaco onde o mesmo se insere.

${ }^{6}$ Vide sobre este pormenor técnico, a descrição dada por HAUSCHILD, 1991, p. 112 . 
tivos que apontam datações recuadas - presença de todos os elementos do capitel canónico; existência de scamillus - por outro, encontramos motivos que nos parecem, de certa forma, anacrónicos dentro desse quadro: flores do ábaco; horizontalidade das volutas e hélices; acentuada curvatura das caneluras centrais. Ainda que não nos possamos esquecer que estamos perante um exemplar inacabado, torna-se difícil imaginar o trabalho final perante o que consideramos serem talhes incorrectos. A presença de vários pormenores decorativos faz pressentir um resultado final talvez atribuível a épocas recuadas. Esta ideia é sublinhada pelo facto de o outro exemplar que a seguir analisaremos apresentar algumas características que se afastam nitidamente daquelas que aqui se encontram apenas esboçadas.

O acentuado efeito de claro/escuro, a sucessão de volumes provocada por uma marcada projecção de alguns dos elementos, assim como o recurso ao uso do trépano, leva-nos a integrar esta peça numa linha evolutiva de tradição flaviana ainda que já degenerada, onde alguns motivos surgem simplificados e fazendo um maior recurso a efeitos de luzes e sombras e a um tratamento bidimensional dos elementos. Deste modo, e reiterando todas as reservas que se deparam quanto à análise de uma peça inacabada, apontaríamos o séc. II como a época da sua realização.

\subsection{Capitel 2}

Capitel coríntio canónico de dimensões muito semelhantes ao exemplar anterior (Fig. 3). Se em relação àquele observámos uma fase de laboração ainda não finalizada, poderíamos dizer, numa primeira observação, que este último corresponde a uma etapa mais avançada de talhe, apesar de alguns pormenores parecerem, de igual forma, não estar ainda concluídos.

A estrutura das duas peças é muito semelhante. Temos, do mesmo modo, duas coroas de folhas compostas por lóbulos que se dispõem paralelamente apresentando um perfil arredondado na sua terminação. Também aqui, e analisando as folhas da imma folia, estão presentes cinco lóbulos (Fig. 6), agora organizados em conjuntos, já que nos surge representado um lóbulo extremo e um outro mediano, cada um com várias folhinhas. Uma breve incisão demarca os lóbulos e as pequenas folhas destes entre si, ainda que a superfície seja lisa, não se 
apresentando bilobados como acontecia no anterior exemplar. Pequenos pontos de trépano continuam a marcar lateralmente o local das separações lobulares. Apesar de alguns mal se notarem devido ao desbastamento e acabamento mais pormenorizado, outros há onde esse tratamento não foi realizado, conservando-se ainda demasiado nítidos os furos atribuíveis ao trabalho do trépano.

Inferiormente, é possível observar nas uniões interlobulares um ponto de trépano de cada lado da nervura central da folha, adoptando a forma de gota alongada com uma ligeira inclinação. Um pormenor de grande importância é-nos dado pelos lóbulos inferiores, onde se pode observar uma nítida sobreposição entre eles (Fig. 6), aspecto que é evidenciado por Pensabene (1973 208) ${ }^{7}$ a par de outros autores, e funcionando este pormenor decorativo como um indicador precioso na definição da cronologia deste tipo de peças. Esta característica é, no caso vertente, bem evidenciada. Se em alguns capitéis dificilmente se consegue observar esse pequeno efeito, outros há, como é o caso de um capitel proveniente de Segóbriga, datável do séc. II (GuTIERREz BeHEMERID $1992116 \mathrm{n} .^{\circ}$ 524), onde este pormenor ornamental pode ser claramente observado. A restante decoração deste exemplar mostra-se muito próxima da peça olisiponense.

A nervura central aparece representada por dois sulcos ligeiramente arqueados que divergem para o exterior na sua parte inferior. Uma pequena nervura central e vertical, somente incisa, marca o eixo da folha. Esta composição aproxima-nos de peças ostienses que seguem a tradição flávia ostentando o centro da folha decorada com caneluras, ainda que em alguns casos se observem pequenos traços oblíquos.

A terminação inferior deste elemento central oferece-nos um acabamento diferente ao do exemplar ostiense. As nervuras criadas pelos sulcos laterais apresentam uma terminação apontada, observável na maioria das folhas, sendo realizada com talhe levemente biselado. É-nos difícil encontrar paralelos para esta composição, facto que nos pode traduzir uma característica própria de um atelier.

$\mathrm{Na}$ summa folia encontramos folhas semelhantes, ainda que alguns pormenores as distingam. Na nervura central desaparece o traço

7 "Negli esemplari augustei o primissimo giulio-cláudi le flogietteche formano le zone d'ombra, l'ultima del lobo inferiore e la prima di quello contiguo superiore, semplicemente si toccano senza sovrapporsi mentra presto e definitivamente la folgletta del lobo inferiore sisovrapporrà a quella del lobo superiore". 
inciso a meio e os sulcos, realizados a bisel, acompanham toda a altura da folha a qual se desgarra, superiormente, do kalathos.

Os lóbulos, organizados em conjuntos de três folhinhas - mais evidentes na parte inferior da folha - mostram o mesmo pormenor da sobreposição lobular. A terminação arredondada ou em forma de gota de alguns parece, por vezes, não ter sido concluída devido ao acabamento imperfeito ${ }^{8}$. Este pormenor contrasta com o aspecto geral das folhas da coroa superior. Estas, apesar de não serem mais largas, encontram-se menos contidas e os contornos são mais libertos, sendo a terminação de alguns lóbulos acentuadamente apontada, o que oferece uma menor rigidez aos motivos e um efeito mais naturalista. $\mathrm{O}$ aspecto mais rígido que estas folhas da imma folia ostentam dever-se-á, essencialmente, à técnica empregue. Com efeito, percebe-se que existe um talhe prévio da folha - e consequente desbastamento - antes de serem realizados os acabamentos posteriores?.

Entre as folhas da imma follia e elevando-se por cima das folhas da coroa superior, dispõem-se os caulículos decorados por dois sulcos longitudinais e por uma orla superior de perfil convexo ornamentada por pequenos sépalos. É nítida a verticalidade destes elementos, apenas ligeiramente inclinados na parte superior e afastando-se, assim, do eixo da peça. Ainda que não se aproximem dos típicos caulículos dos finais do séc. II - caracterizados por apresentarem uma maior simplificação e reduzindo a decoração a um único sulco central - os caulículos que agora analisamos anunciam já uma certa esquematização, sendo a sua ornamentação reduzida a traços simplificados - dois sulcos verticais; convexidade da superfície somente no espaço definido por aqueles; breves incisões na parte superior da orla.

Encobertos sob as folhas contíguas, os caulículos dos finais do séc. II e do séc. III assumem um papel secundário na decoração da peça, aspecto que, se no presente exemplar não é acentuado, denuncia uma certa simplificação.

Dos caulículos arrancam duas meias folhas de perfil, que suportam, respectivamente, as faixas correspondentes aos canais das volutas e das hélices. As caraterísticas foliáceas são semelhantes às anterior-

8 Aspecto que é sublinhado pela secção quadrada que algumas das folhinhas apresentam na sua parte final.

9 Aspecto que podemos constatar em exemplares do séc. II, sobre este aspecto cf. PENSABENE 1973226. 
mente (Fig. 7) descritas, ainda que, no caso vertente, a terminação quadrada de alguns dos lóbulos seja mais frequente.

No meio destas duas meias folhas observa-se uma pequena folha trilobada que se apresenta frontalmente destacando-se das outras duas mais elevadas. Um pequeno ponto de trépano surge no seu centro. Este será um pormenor decorativo que apenas aparece documentado a partir dos inícios do séc. II, como podemos averiguar em capitéis deste período provenientes de Itálica, Ecija (Sevilha), ou de Mérida (GuTIERREZ BEHEMERID 1992106 e 107 - n. ${ }^{\text {os }} 443 / 448 / 452 ; 108$ - n. ${ }^{\circ} 461$ ).

Como observámos no exemplar anterior, também aqui a proporção entre os dois registos inferiores - imma e summa folia - e o superior - hélices, volutas e ábaco - não segue os padrões canónicos do séc. I, concedendo uma notória importância ao primeiro em detrimento do segundo, o que se traduz numa explanação mais contida dos motivos decorativos do registo superior obrigando, deste modo, a uma maior horizontalidade das volutas e hélices, elementos que contrastam com a verticalidade dos elementos inferiores - folhas e caulículos. Esta alteração da proporção do capitel torna-se mais notória a partir dos finais do séc. I, sendo mais acentuada na seguinte centúria.

Volutas e hélices encontram-se representadas por faixa larga e lisa, de enrolamento espiraliforme na sua parte terminal sendo o botão central sobreelevado. Ainda que aqui as hélices se encontrem explanadas, é de sublinhar a sua pouca altura. $\mathrm{O}$ espaço entre as meias folhas das hélices não se encontra decorado, apresentando-se o kalathos liso. Os enrolamentos das hélices são justapostos, sendo a união axializada e sobreposta pela flor do ábaco. Curiosamente, não está representada a haste da flor, o que, possivelmente, se ficará a dever ao não acabamento do exemplar.

A união das volutas na sua parte frontal (ao contrário da solução detectada nas hélices) é estabelecida por uma pequena faixa que faz a separação entre as duas volutas contíguas.

O ábaco é decorado por uma moldura alta e ligeiramente convexa que se sobrepõe a uma banda mais reentrante e de perfil ligeiramente oblíquo. A moldura mais frequente, no entanto, possui um pequeno listel (simples ou directo) unindo as duas molduras, como podemos observar em, praticamente, todos os exemplares ostienses dos sécs. I e II. Os lados são côncavos e a parte central é decorada por uma roseta de cinco pétalas e com botão central relevado. A flor é côncava, de igual modo, e ligeiramente inclinada para baixo, artifício usado habitualmente com o objectivo de possibilitar a visualização deste elemento. 
Como na peça anterior, também aqui podemos observar um pequeno scamillus, mais reentrante em relação ao diâmetro do ábaco, elemento que confirma o cuidado técnico e o perfeito conhecimento das técnicas então em uso na realização deste tipo de peças.

Pelas características apresentadas datamos este exemplar da primeira metade do séc. II.

\section{ANÁLISE TÉCNICA E ESTILÍSTICA}

O exemplar 2 corresponde a um capitel na sua última fase de acabamento, sendo que, a alguns dos seus elementos decorativos, faltam ainda os retoque finais, tal como podemos observar no cesto da peça por baixo das hélices - onde está ausente o caule da flor do ábaco - ou ainda em alguns lóbulos cuja finalização parece não estar concluída.

Em alguns locais é utilizado o trépano de ponto sem qualquer tratamento posterior, o que nos permite observar a sua cuidada execução. Em outros casos, o trépano pontual sofre um alongamento a fim de tornar mais naturalista a composição decorativa. Os motivos são desenhados e esculpidos com cinzel de ponta e de bisel.

Os elementos foliáceos mostram-nos uma particularidade: trata-se do facto de as folhas de ambas as coroas possuírem, na nervura central - e a uma altura constante - um pequeno ponto rebaixado feito com broca, realizado de forma suave. Este pormenor indica-nos a marcação prévia no bloco pétreo, já desbastado, do eixo das folhas, denotando uma conceptualização prévia do trabalho a executar.

A zona do kalathos, não decorada, apresenta uma textura pouco regular, afeiçoada a escopro de ponta recta ou, talvez, a cinzel gradilhado. A superfície, homogénea, evidencia a utilização de abrasivos de afeiçoamento.

O capitel 1 documenta-nos uma fase intermédia de realização, em que os diversos motivos ornamentais se encontram esboçados mas aos quais falta o respectivo acabamento. O emprego do trépano é bem evidente, sendo perceptíveis os respectivos pontos aos quais falta um último acabamento que consistiria na sua união. Este trabalho de pormenor deveria ser realizado com cinzel de ponta.

A superfície destas peças não evidencia o uso de abrasivos de polimento o que se deverá, em grande medida, ao facto de as peças não se encontrarem concluídas. 
Estas duas peças afastam-se de uma sobriedade estilística que podemos encontrar no primeiro século da nossa era. Não obstante, os pormenores evidenciados anunciam um novo gosto, que busca novos efeitos cénicos através de novas técnicas de execução. Os volumes são muito mais fortes, sendo igualmente mais acentuada a bidimensionalidade dos relevos, desvirtuando a antiga plástica modeladora dos diversos motivos.

Os sulcos, o trépano, as nervuras, surgem-nos marcadas na pedra sem que exista uma relação de continuidade entre os mesmos. As folhas, por exemplo, ilustram-nos bem este aspecto: o contorno, inicialmente contínuo, foi posteriormente talhado e enriquecido com novos elementos que sofreram um tratamento autónomo, apresentando-se plana a superfície foliácea sem evidenciar qualquer curvatura naturalista. Os vários elementos são tratados de forma individual ainda que não exista uma definição pormenorizada dos mesmos. As terminações lobulares apresentam erros de talhe acentuados, finalizando em corte brusco sem que seja realizada uma terminação arredondada que, não obstante, se pode observar em alguns dos lóbulos.

O conjunto, no entanto, não deixa de ser atractivo residindo, precisamente nesse facto, o objectivo do canteiro, do artífice, do atelier que o produziu: o de oferecer uma obra agradável à vista. Encontramo-nos assim, perante uma decoração que, estilisticamente, descura as definições ornamentais, para se debruçar nos efeitos plásticos de conjunto. Esta será uma característica de época flávia, onde o efeito de luz e sombra será o pretendido. Com efeito, o trépano é largamente empregue, ainda que sem o exagero que, por vezes, se denota em peças dessa época, tornando pertinente a designação de "barroquismo flávio". Alguns dos elementos são destacados do corpo da peça, como podemos observar nas volutas, as quais se projectam externamente de forma a acompanhar o contorno do ábaco. O próprio enrolamento terminal destes elementos é exageradamente relevado, sendo notória a intenção do artífice de procurar um maior efeito plástico.

\section{INTEGRAÇÃO ARQUITECTÓNICA E CENTROS OFICINAIS}

O facto de as peças que agora analisamos serem idênticas, identificando-se com fases distintas de acabamento, leva-nos a considerar 
estarmos em presença de exemplares provenientes de um mesmo atelier e, decerto, localizado próximo do local onde foram encontrados.

Com efeito, a similitude técnica e estilística, a par das idênticas dimensões que apresentam, sugerem estarmos perante capitéis que se destinavam a integrar um mesmo edifício. Ainda que, actualmente, desconheçamos que monumento ou monumentos de época romana poderão ter existido nas imediações da actual Rua das Padarias, não podemos deixar de referir a hipótese indicada por Cardim Ribeiro, o qual propõe a área compreendida entre a Rua das Padarias e a Rua dos Fanqueiros como o local onde se situaria o forum municipal de Olisipo (RIBEIRO 199484 fig. 3).

$\mathrm{O}$ aspecto mais importante, quanto a uma possível integração arquitectónica destes exemplares, refere-se ao facto de, na segunda centúria - de acordo com a cronologia destes dois capitéis - se comprovar que a cidade continuaria com uma política construtiva de alguma importância. Ainda que este programa edificatório não possa ser equiparado ao detectado no séc. I - o qual se integra num programa urbanístico da cidade aquando do início da ocupação pelo novo poder político - a segunda centúria poderá corresponder a uma continuação dessas novas directrizes, ainda que caracterizada por um menor volume de construções ou, provavelmente, por uma renovação dos espaços públicos com o objectivo de se adequarem a novos modismos construtivos e programas decorativos.

A qualidade documentada por estes espécimes, assim como o léxico ornamental - perfeitamente integrado nas correntes documentadas no centro do império - ilustra-nos que a ordem arquitectónica coríntia passou a ser do agrado dos olisiponenses a partir da segunda centúria. Com efeito, os capitéis jónicos do teatro romano, aqueles que certamente decorariam a frons scaenae, são peças jónicas realizadas em estuque - no que respeita aos pormenores decorativos - e deverão ser interpretadas como elementos da época de construção do teatro ${ }^{10}$. Os capitéis coríntios que aí nos surgem (em número de sete), e de idêntica cronologia, deverão ter ocupado um lugar de menor relevância naquele espaço público, outro que não a frons scaenae.

10 Ou seja, os inícios do séc. I d.C. A fase de remodelação do teatro, operada em 57 d.C tal como nos é documentada pela inscrição existente no muro do proscaenium, apenas terá abrangido esse mesmo muro, assim como a pavimentação da orchestra e, provavelmente, a ornamentação do espaço interior com estatuária. Os vários elementos arquitectónicos do muro de cena não deverão, em nossa opinião, ter sofrido alterações. 
As restantes peças que conhecemos em Lisboa são, na sua maioria, capitéis também jónicos, mas integram-se num contexto tardio totalmente distinto quando a ordem jónica, já desvirtuada e produzindo peças de menores dimensões e proporção, é de novo reabilitada sendo do apreço dos habitantes da cidade para a decoração de edifícios particulares ${ }^{11}$. Desconhecemos, no entanto, quais os programas decorativos dos edifícios públicos que se construíram em Olisipo em época tardia.

O tipo de material empregue - pedra de lioz - pode-nos fornecer, de igual modo, algumas informações, sobretudo se tomarmos em consideração as peças anteriormente referidas do teatro romano de Lisboa. Se, nestes últimos, se emprega o urgeiro - calcário conquífero local - revestido a estuque, observamos que as posteriores remodelações operadas em 57 d.C, passam a empregar a pedra de lioz - geralmente confundida com mármore, venada a branco, quer nas pedras de coloração cinza quer nas de cor rósea.

Esta alteração do tipo de material podemos observá-la em Olisipo e, de igual forma, em Mérida ${ }^{12}$, o que nos traduz uma mudança no que respeita às soluções decorativas utilizadas na primeira fase de urbanização das cidades e aquelas que vão ser aplicadas a partir da época Júlia-Cláudia. Quanto ao primeiro momento podemos interpretar essas soluções decorativas como "adaptações provinciais", uma vez que empregam a matéria-prima local “... y cuyos criterios decorativos deben englobarse en las corrientes denominadas provinciales o relacionarse en todo caso com las de los primeros años de la época augustea en Italia central" (JAVIER GIMENO 1992 95). As modificações introduzidas no léxico decorativo provincial em épocas tardias júlio-claudianas e durante o período flávio, reger-se-ão segundo distintos modelos alterando, assim, o tipo de funcionamento dos centros de produção.

A distinção que podemos observar entre, por um lado, os capitéis do teatro romano de Lisboa e a respectiva remodelação de 57 d.C e, por outro, os capitéis coríntios da Rua das Padarias obriga-nos, consequentemente, a considerar novos critérios ornamentais. Utilizando materiais mais nobres - o mármore ou o lioz em vez do calcário urgeiro revestido a estuque - os modelos a imitar relacionam-se, ou directamente com os constatados no centro do Império ou, por via indirecta, através de Mérida. São relevantes, quanto a este aspecto, os paralelismos apontados

11 Sobre estas peças vide FERNANDES 1997 vol. II, III e IV: peças n. ${ }^{\text {os }}$ 53, 54, 56.

12 E em outras cidades provinciais. 
para os capitéis da Rua das Padarias com peças ostienses. O caso de Tarraco, por exemplo, pode oferecer-nos um paralelismo marcante, sendo evidente uma alteração do tipo de materiais empregues entre a época augustana e o período júlio-claudiano caracterizado, este último, pela enorme afluência de mármore e, desse modo “... a un sistema de importación que, según puede desprenderse tanto del material en sí como de la morfologia de las piezas, parece organizarse en un esquema de relación exclusiva com estructuras y talleres de la propria Roma” (JAVIER GIMENO 1992 95).

\section{BIBLIOGRAFIA}

BarRera Anton, José Luís de la, "Los capiteles romanos de Mérida, Monografias Emeritenses 2 Badajoz 1984

Carlos Marquez, Capiteles Romanos de Corduba Colonia Patricia, Córdoba 1993 Cencialoli, Luana, "I capitelli romani di Perugia", Studi Classici 1, Annales della Facolta della Universita degli Studi de Perugia XV Perugia 1977-78

Cressier, Patrice, "Le chapiteau Emiral: les problèmes de son étude", Coloquio Internacional de Capiteles Corintios Prerromanicos e Islamicos (ss. VI-XII d.C), Madrid 1990 87-102

Cruz Villalón, Maria, Mérida Visigoda - La Escultura Arquitectónica e Litúrgica Badajoz 1985

Díaz Martos, Arturo, "Los capiteles romanos de orden corintio de España y problemas de su estudio", Ampúrias XXII-XXIII Barcelona 1060-61 223-237

FernANDES, Lídia; VALE, Ana, "Intervenção arqueológica no Largo de St. ${ }^{\circ}$ António da Sé", Almadan, Centro de Arqueologia de Almada, II..$^{a}$ Série, 3 Almada 1994109 Fernandes, Lídia, Capitéis Romanos da Lusitânia Ocidental, Dissertação Final de Mestrado apresentada à Faculdade de Ciências Sociais e Humanas da Universidade Nova de Lisboa Vol. I - IV Lisboa 1997

Fernandes, Lídia, "Elementos arquitectónicos de época romana da Casa dos Bicos - Lisboa, Conimbriga, 371998 113-135

GuTIERREZ BeHEMrID, M." Angeles, "Sobre la sistematizacion del capitel coríntio en la Peninsula Ibérica", Boletin del Seminario de Estudios de Arte y Arqueologia XLVIII Valladolid 1982 25-44

Gutierrez Behemerid, M. a Angeles, "Capiteles romanos de la Peninsula Ibérica", Studia Archaeologica 81 Valladolid 1992

HAUSCHILD, Theodor, "Das römische Theather von Lissabon, Planaufnahme 1985-88", Madrider Mitteilungen 31 Mainz 1990 348-392

HAUSCHILD, Theodor, "El templo romano de Évora", Templos Romanos de Hispania, Cuadernos de Arquitectura Romana 1 Múrcia 1991 107-117 
JAVIER Gimeno, "Un conjunto de capiteles de origen Asiático en Tarraco y Barcino reflexiones sobre la importación de elementos orientales en la arquitectura del nordeste de Hispania a partir del siglo II d.C.", Archivo Español de Arqueologia 65 Madrid 1992 75-103

Pensabene, Partizio, Scavi di Ostia - I Capitelli, VII Roma 1973

Ribeiro, José Cardim, "Felicitas Iulia Olisipo - algumas considerações em torno do catálogo Lisboa Subterrânea", Almadan, II. e. série 3 Almada 1994 75-95 


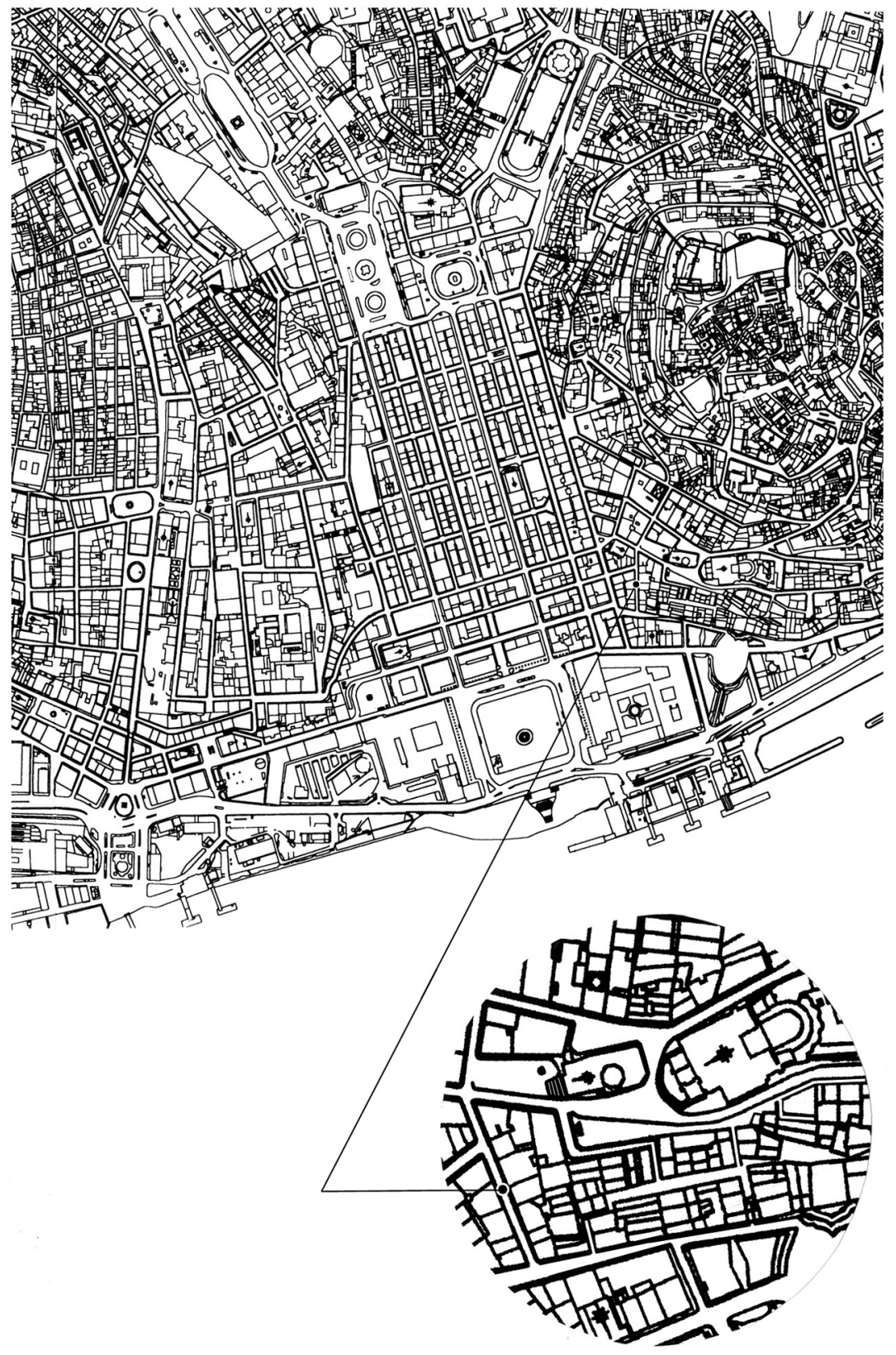

FIG. 1 - Marcação da Rua das Padarias onde terão aparecido os dois capitéis. Neste mapa podemos visualizar onde, em época romana, se localizaria o teatro romano, bem como o criptopórtico ou galerias romanas da Rua da Prata (mapa adaptado de HauschILD, 1990, Abb. 1). 


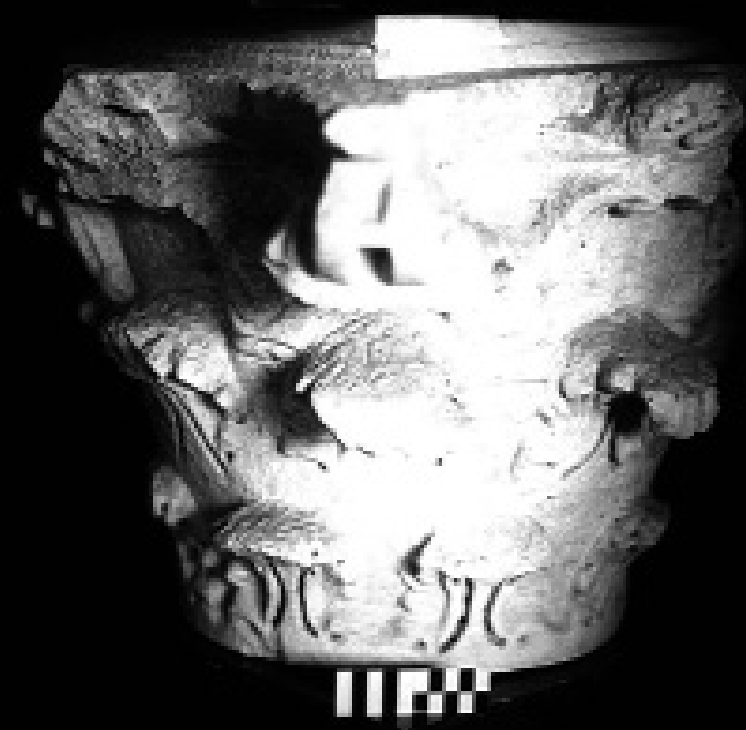

FIG. 2 - Capitel coríntio n. ${ }^{\circ} 1$

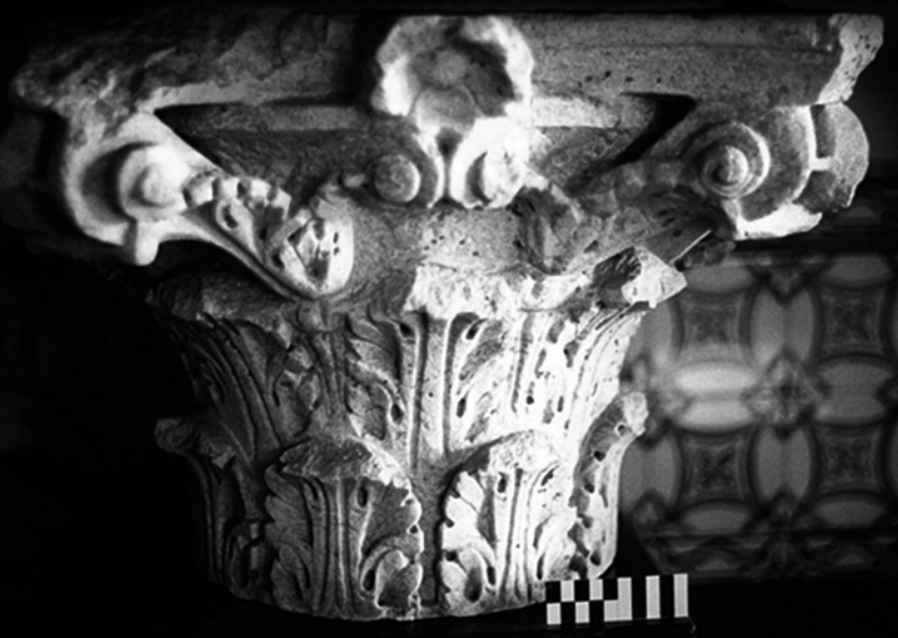

FIg. 3 - Capitel coríntio n. ${ }^{\circ} 2$ 


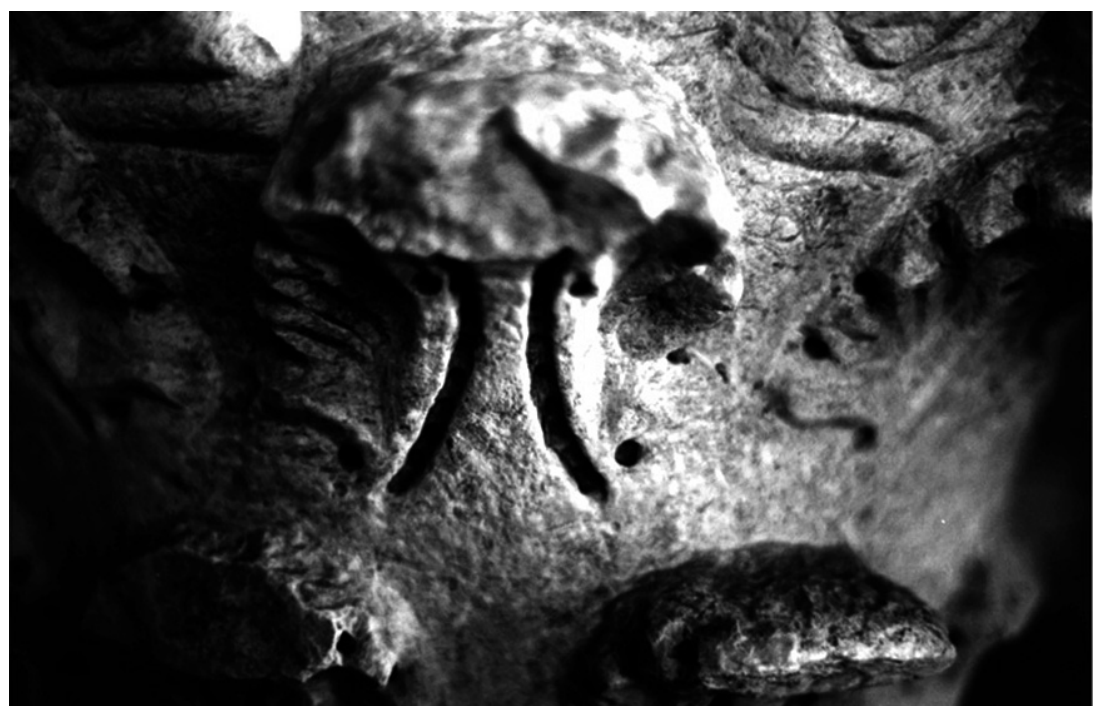

FIG. 4 - Capitel coríntio n. ${ }^{\circ}$ 1. Pormenor das folhas da summa folia.

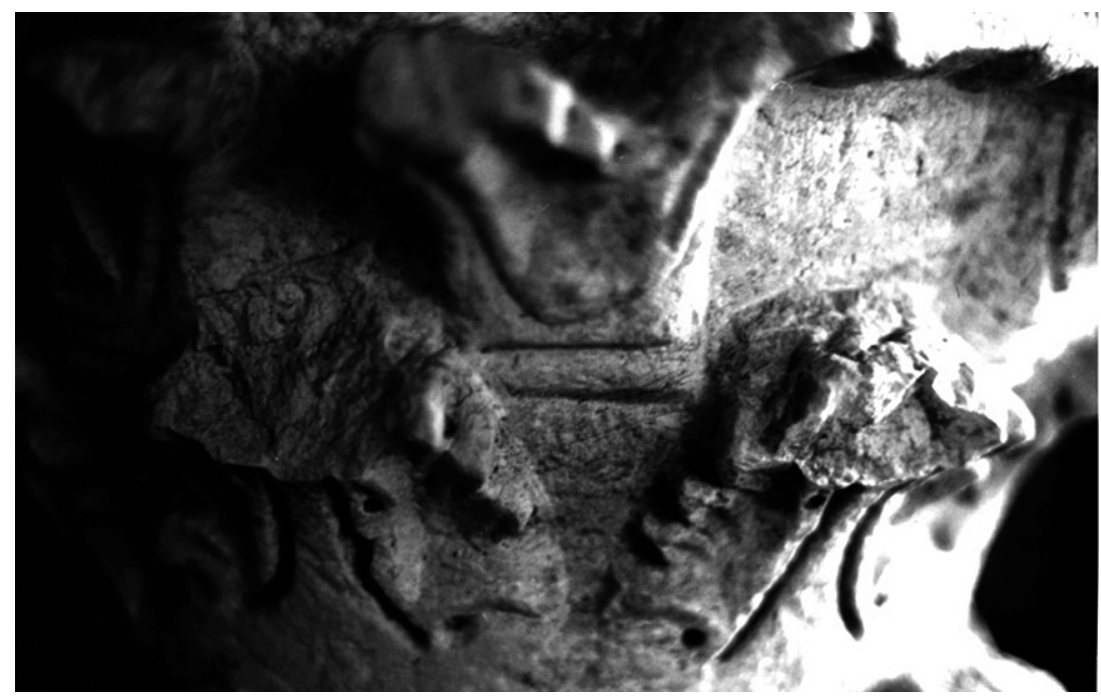

FIG. 5 - Capitel coríntio n. ${ }^{\circ}$ 1. Pormenor do caulículo e do arranque das hélices e volutas. 


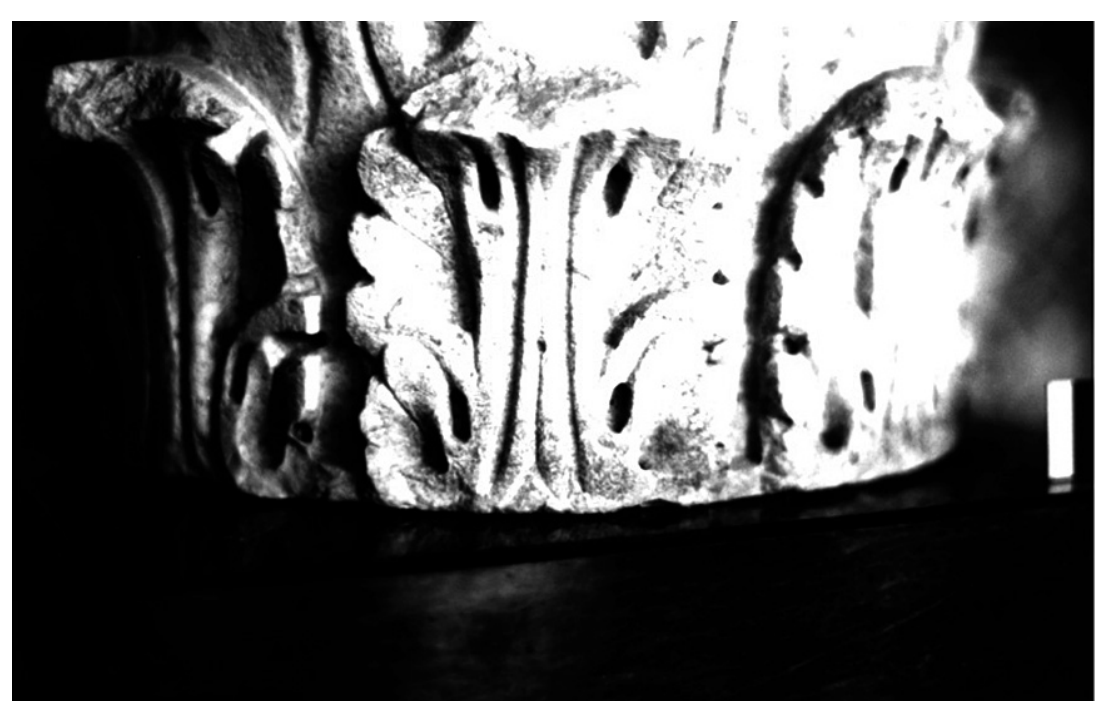

FIG. 6 - Capitel coríntio n. ${ }^{\circ}$ 2. Pormenor das folhas da imma folia .

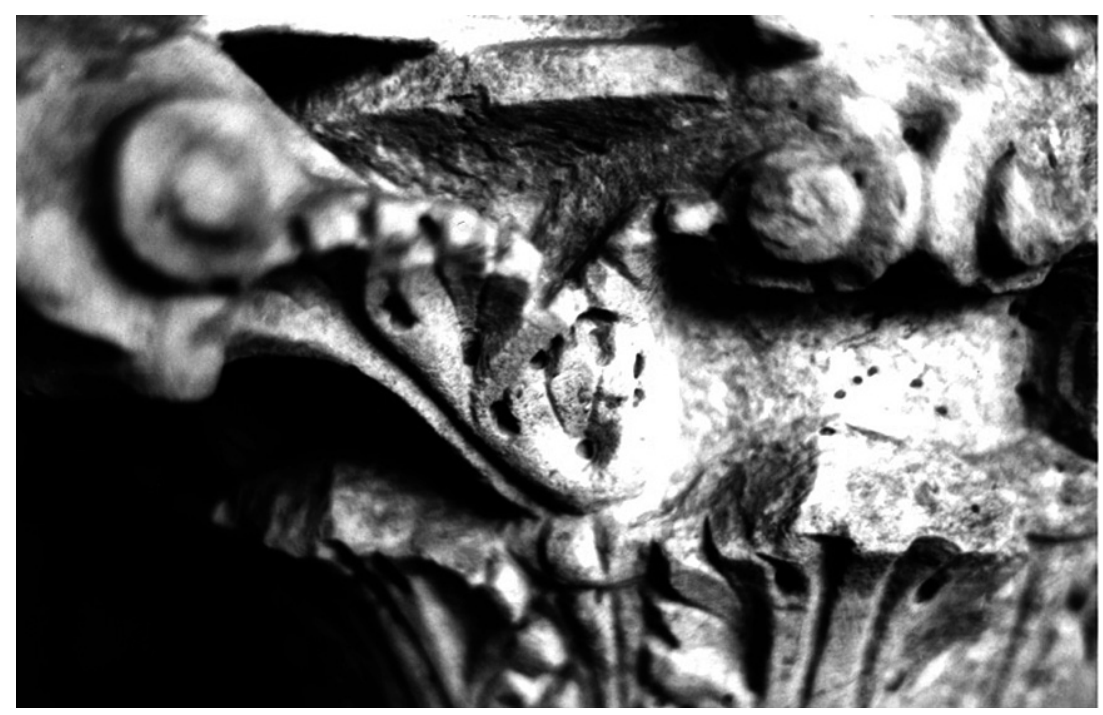

Fig. 7 - Capitel coríntio n. ${ }^{\circ}$ 2. Pormenor da parte superior dos caulículos e do arranque das hélices. 